\title{
THE TRICKSTER WINK: STORYTELLING AND RESISTANCE IN TOMSON HIGHWAY'S KISS OF THE FUR QUEEN
}

\author{
Rubelise da Cunha \\ Universidade Federal do Rio Grande
}

\section{Abstract}

This essay explores how Tomson Highway uses the narrative genre as a space to perform a speech act of resistance against colonialism through an approach that departs from contemporary discussions on genre theory and theories of storytelling. Highway's novel Kiss of the Fur Queen reaffirms the process of adaptation that is intrinsic to Indigenous cultures and to the survival of the Trickster and promotes a healing experience through the recovery of Cree storytelling. John Frow's concept of genre as a performative structure that shapes the world in the very process of putting it into speech contributes to the focus on Indigenous storytelling rather than on Western literary categories.

Keywords: Tomson Highway, storytelling and resistance.

\section{Weesageechak in New Guises: Re-Establishing the Trickster}

In "Compromising postcolonialisms: Tomson Highway's Kiss of the Fur Queen and contemporary postcolonial debates," Diana Brydon

\begin{tabular}{|l|l|l|l|l|}
\hline Ilha do Desterro & Florianópolis & no 56 & p. 093-118 & jan./jun. 2009 \\
\hline
\end{tabular}


mentions that both Thomas King and Tomson Highway, who are writers known for their popular comic troping on serious themes, have turned to darker visions in their more recent texts. According to Brydon, since their humor has made Euro-Canadian audiences laugh, it has helped move them into mainstream acceptance, bringing their political effectiveness into question (15). Humor promotes a healing experience and, although the comic aspect is not so clearly perceived in Kiss of the Fur Queen, Highway does not abandon what Brydon calls "the ludic play that signals survival and the triumph of a perspective that refuses to be silenced" (15). In Highway's works, ludic play survives through the triumph of the Trickster, a figure that is able to balance the pain of colonialism with humor, and to adapt into Western cultural forms of discourse to resist colonialism and survive in the contemporary world.

Postcolonial, postmodern, psychological and queer theories have been used to approach Highway's novel. In "Towards a recognition of being: Tomson Highway's Kiss of the Fur Queen and Eden Robinson's Monkey Beach," Coral Ann Howells points out that Highway's novel is a striking example of hybridized text, where different cultural systems of representation are held together in tension (147). This concept of hybridity as two systems in tension that Homi Bhabha fully develops in his text "Minority cultures and creative anxiety" (2000) is useful to explain how colonial education and Western symbolic figures are coparticipants in Highway's discourse of resistance. However, an Indigenous-centered approach which shows how Cree storytelling is able to resist Western culture by its power of adaptation is fundamental to understand Highway's discourse on the border of two worlds. I align myself with Brydon in her position that a postcolonial approach is partial to the analysis of Kiss of the Fur Queen. Brydon points out that postcolonial theory is productive when in dialogue with other perspectives, and argues for acceptance of postcolonial literary critique as "a partial, provisional, and imperfect approach that nonetheless allows pressing questions to be asked about the relations of text and world, the limits of disciplinarity and interdisciplinarity; and the multiple 
contexts in which postcolonial critics conduct their work" (16). Brydon believes that "coalitional politics based on a shared identification of interests within a specific social context stand a greater chance of promoting agency" (19). Highway's Trickster in Kiss of the Fur Queen can be read within a coalitional politics that merges Cree storytelling and Western discourse in order to promote healing and redemption for those who have faced colonial oppression, represented in the novel by the residential school experience. In this paper I explore how Highway uses the narrative genre as a space to perform a speech act of resistance against colonialism. It is by reaffirming the process of adaptation intrinsic to Indigenous cultures and to the survival of the Trickster that his novel promotes a healing experience through the recovery of Cree storytelling. My objective is to analyze resistance to colonialism in Highway's novel through an approach that departs from genre theory and theories of storytelling.

In his book Genre (2005), John Frow explains that his concept of genre as a performative structure that shapes the world in the very process of putting it into speech (18) is very close to what Foucault calls discourse - "practices that systematically form the objects of which they speak" (49), and it is a medium or system of representation that fosters the comprehension of cultural phenomena. Frow explores how genres actively generate and shape knowledge of the world, so that they become "a form of symbolic action: the generic organization of language, image, gestures, and sound makes things happen by actively shaping the way we understand the world" (2). If, according to Frow, genre is a performative structure, a category in motion which constructs knowledge, the novel can also become a medium for the resurrection of storytelling so that knowledge that reaffirms the continuation of Indigenous cultures is constructed. Salish writer and critic Lee Maracle has emphasized how more effective and profitable it is for Indigenous people to see themselves through the story (55), and not through Western paradigms. Although it is fundamental to acknowledge that she refers specifically to Salish storytelling and oratory, she also 
contributes to a questioning of preconceived Western literary approaches to Indigenous literatures generally, pointing to the meaning and function of stories. Maracle's theorizing about storytelling takes into account the written texts, which become the rememberers of the story in the modern world (67), and she develops her argument through a perspective that acknowledges the story, the listener/reader and the process of transformation that results from this experience. Her focus on story as a genre also establishes a dialogue with the concept of genre as performance, or as language that acts and is transformative: "The point of hearing (and now reading) story is to study it in and of itself, to examine the context in which it is told, to understand the obstacles to being that it presents, and then to see ourselves through the story, that is, transform ourselves in accordance with our agreement with and understanding of the story" (55).

Anthropologist Julie Cruikshank, in her collaborative work with three female Elders between 1974 and the 1980s, provides insights into the function of stories for the Yukon people. Her work is published in the coauthored book entitled Life Lived like a Story (1990) and in a subsequent book called The Social Life of Stories: Narrative and Knowledge in the Yukon Territory (1998). In this second book, she comments that one of the many things these women taught her is that "their narratives do far more than entertain. If one has optimistic stories about the past, they showed, one can draw on internal resources to survive and make sense of arbitrary forces that might otherwise seem overwhelming" (xii). Cruikshank shows how the story constitutes much more than the words pronounced or the narrative told, since it has a practical and fundamental role in the lives of the peoples. When acknowledging the storytelling practice of Mrs. Sidney, one of the three Elders, she states that "when potential for conflict emerges among people with different perspectives, successful resolution often involves demonstrating how a story can reframe a divisive issue by providing a broader context for evaluating such issues" (xv). Her ideas also converge with the meaning that Maracle attributes to stories as being 
fundamental for the healing and survival of the people. Cruikshank also mentions the relationship established between the communities and the transcribed texts, and how the Yukon Elder storytellers point to writing as just one more way to tell their stories and to make them part of social practice: "Written texts become points of reference narrators can allude to when they want to make socially significant statements to family members, to other members of their community, or to the larger world about the potential of stories to make us reevaluate situations we think we understand" (xiv). Highway's literary works become these points of reference mentioned by Cruikshank, so that the reader community, which replaces the listening community, reevaluates its own role in the colonial experience. Furthermore, the dialogue he establishes between traditional Cree storytelling and the Western literary tradition is able to reconnect these two discursive worlds.

Highway constructs knowledge that resists colonialism by the revitalization of Cree storytelling. In his Charles R. Bronfman Lecture in Canadian Studies published by the University of Ottawa Press, Comparing Mythologies (2003), he offers a definition of mythology that is related to Lévi-Strauss's ideas about the relationship between language, story and myth. Going back to the Greek etymology of the word, Highway reminds us that "myth" is narrative, story, whereas "logos" is "word" or "discourse," so that mythology becomes the "art of storytelling." In Cree, "mythologize" is a word that belongs between the words that mean "to tell a story," "to tell the truth" and "to tell a lie" (22). In short, mythologies are halfway between truth and lie, nonfiction and fiction. They tell the stories of the spiritual movements of peoples across the landscape. One of the great contributions of Highway's lecture is to compare, on the same level, the three mythologies that influence the Canadian culture and imaginary: Christian, Greek and Indigenous mythologies. While Lévi-Strauss uses a Western definition of myth to analyze the structure of myth in "other" cultures, searching for common patterns, Highway highlights that colonialism and the mythologies that came with the Europeans are part 
of a story that arrived in Canada only in 1492. At that time, Mother Earth was a powerful entity long before the patriarchal God came to subjugate her. According to Highway, mythology is the language that explains what science and religion cannot, that is, the origin of life. This is the dream world where beings like the Indigenous Trickster walk: half-woman, half-fish, half-man, half-coyote. This "most elaborate of all fictions" (49), halfway between truth and fiction, is the language or discourse in which figures such as Raven, Coyote, Rabbit, Hare, Nanabush, Weesageechak and other storytelling figures of Indigenous cultures are found.

The centrality of the Cree/Ojibway Trickster Weesageechak/ Nanabush is observed in Highway's works since his first plays, and stressed by his participation in the Committee to Re-Establish the Trickster, the group he founded in 1996 together with Lenore KeeshingTobias and Daniel David Moses. The idea of re-establishing the Trickster, which motivated the group and is present in Highway's works proposes a resurrection of Indigenous knowledge and, for Highway, Indigenous mythology in Canadian literature and art. From an Indigenous perspective, art and literature, which are included in storytelling, connect the material and the spiritual, the human and the divine. Since the Trickster is the central figure who plays the greatest role in relaying messages between the divine force and humankind in the flesh, Highway considers that his presence in literature is the best expression of Indigenous knowledge in literature (Shackleton and Lutz 76-77). In "Traditional Values and Modern Concerns: the Committee to Reestablish the Trickster," Gundula Wilke acknowledges the group and the importance of the Trickster for Indigenous writing. Wilke states that Highway recreates and reworks Indigenous mythology in order to communicate with the Indigenous subject who has moved into urban life. In Highway's words, in order for these myths to be relevant for his life, to his own system of spiritual beliefs, he has to "apply these myths, this mythology to the realities of city living" (29).

Wilke also explains that this adaptation to new situations is something intrinsic to Indigenous cultures and mythologies, saying 
that "Native, orally transmitted mythologies, and Native cultures have never been static but were constantly adapting to new life situations" (10). Her argument works in a more generalized way, since she does not acknowledge any Indigenous culture specifically. Lynn Mario T. M. de Souza shares Wilke's ideas when analyzing the culture of the Kashinawa in Brazil and the symbology of the logic of their cultural hero - the anaconda spirit. He points out that the openness to a radical otherness, which is dangerous and at the same time desirable, is symbolized in Kashinawa culture by the figure of the anaconda that cyclically changes its skin, and survives due to its necessary and constant periodical changes. De Souza explains that this openness to alterity and change does not represent loss or diminishing authenticity, but "the vitality that comes from the exterior, which, like the anaconda, remains the same by constantly changing skin" (15). In Highway's plays and in his novel, the Trickster emerges in new guises after the contact with the dangerous otherness of Western culture, and might have learned the lesson that it is not by a quest for lost authenticity, but by adaptation that Indigenous knowledge and culture may survive.

\section{Kiss of the Fur Queen}

Tomson Highway's first novel, Kiss of the Fur Queen (1998), centers on the figure of Weesageechak as a strategy of healing and redemption, recovery of Cree culture, and resistance to a history of colonialism. Based on the author's own experience of colonial impositions in Northern Manitoba, the novel tells the story of the brothers Jeremiah and Gabriel Okimasis, whose Cree names are Champion and Dancer respectively, and the effects throughout their lives of their forced removal from the reserve, Eemanapiteepitat, to a residential school. The 36 years in their lives - from 1951 to 1987 - are organized in this symphony-novel into six parts, which represent movements in classical music: Allegro ma non troppo, Andante Cantabile, Alegretto Grazioso, Molto Agitato, Adagio Espressivo e Presto con Fuoco. Howells identifies Highway's training as a classical 
pianist and a playwright in the novel not only in the Italian musical notations prefacing each section, but also because the narrative is structured as a series of spectacular scenes (152).

The starting point is the year of 1951, when the White Beauty Pageant Fur Queen bestows the congratulatory kiss on the caribou hunter Abraham Okimasis, Jeremiah and Gabriel's father, for his victory in the 1951 Millington Cup World Championship Dog Derby at the Trappers' Festival, Oopaskooyak, Manitoba. This first kiss is immortalized through the storytelling tradition of the family and materialized in the photograph that Jeremiah and Gabriel take with them after leaving home. Moreover, as Diana Brydon states, it "sets the plot in motion and initiates the novel's complex interplay across different realms of spiritual and cultural experience" (20). Through the recovery of Cree traditional storytelling, and also through the narrator's telling of the story in the novel, the Fur Queen travels from the historical to the mythological, and is transformed into the trickster deity that accompanies the boys into their journey: their conception, birth, adventures and hard experiences in the residential school and in adulthood. She greets Abraham with her kiss in his victory and after his death, and also, in Brydon's words, "ushers his beloved youngest son beyond the threshold of death at the novel's heart-rending conclusion" (20), when she takes Gabriel by the hand to another realm. Brydon recovers the biblical references for the two brothers' names: Jeremiah is the prophet of doom and Gabriel the angel of annunciation; Jeremiah ends up as the survivor, and Gabriel is the sacrificial victim. Influenced by Father Bouchard, the priest on the reserve, and by the presence of Catholicism, Abraham and Mariesis Okimasis believe the residential school to be the best option for their children. However, the years of abuse and neglect at the school mark the children's lives forever, not only through the gap between the life in the Cree community in Northern Manitoba and the life at school and later on in the city of Winnipeg, but also through the tragic results of this experience, which in a certain way leads Gabriel to the lifestyle that causes his death from 
AIDS in the end of the novel. However, the Fur Queen's act of taking him to another realm challenges the idea of defeat, since dying contradictorily brings promises of survival.

Kiss of the Fur Queen is based on the life experience of Tomson Highway and his brother René Highway, a famous dancer who died of AIDS in the late 1980's. As Jeremiah and Gabriel, he and his brother passed through the residential school experience. In the novel, Jeremiah is the pianist whose music saves him from the torments lived in the residential school. When he goes to high school in Winnipeg, the piano and his music are the only friends and company he has, until his brother joins him. Gabriel is a talented dancer, who conceals his ballet classes from his brother and friends. The novel culminates in Jeremiah's rediscovery of his roots and his mission, first through Indigenous theatre, in whose plays his brother participates, and later on through the Fur Queen's wink when Gabriel is dying. This process shows how Highway dives into mythology and his memories of the past to talk about the present, performing the process that Cruikshank identifies in the storytelling of the Yukon Elders: "each narrator combines traditional narrative with individual experience to construct a coherent account of her life" (Life Lived like a Story xi). From a personal history of pain and suffering, Highway constructs a literary text that, more than combining the beauty of music and poetical language, is able to sum up the double nature of Weesageechak in the figure of the Fur Queen, who is both a protector and an announcer of destruction, beautiful but the representative of a sad reality, good and bad, life and death. Brydon recognizes the duplicity of this figure in the novel, which represents the survival of Cree knowledge in the adaptation of the trickster Weesageechak:

As a manifestation of Trickster, Highway's Fur Queen performs kiss, smile, laugh, and wink as double-edged enactments of promise and betrayal. She incorporates the pain and pleasure of desire. Her enigmatic presence in the 
heavens above ensures continuity and survival through adaptation and operates to remind the reader of alternative spiritual dimensions. (20-21)

The trickster Fur Queen employs her metamorphosis throughout the novel to reaffirm the survival of the storytelling tradition. Such survival appears in the novel both thematically and structurally. The survival of Jeremiah and Gabriel's transition to another realm by the hands of the Fur Queen represent the victory of Cree culture thematically, whereas the transformation of the Fur Queen to survive in Western and Cree storytelling traditions represents an adaptation of the literary genre so that Cree knowledge continues in the contemporary world. Brydon mentions the dialogue with the bible in the names of the characters, and Coral Ann Howells compares the brothers' journey in the novel to James Joyce's A Portrait of the Artist as a Young Man (148). In this essay I analyze how Cree traditional storytelling adapts into the Western storytelling tradition of fairy tales, as well as how it establishes a conflicting dialogue with the Catholic discourse which culminates in Gabriel's death but also in the survival of the Trickster.

\section{The Fairytale Godmother}

The Fur Queen first appears in the beginning of the novel when Miss Julie Pembrook, from Wolverine River, Manitoba, is the winner of the Beauty Pageant and receives her cash award and a bouquet of white roses. She is described as draped "not only with a white satin sash but with a floor length cape fashioned from the fur of arctic fox, white as day" (9). White is repeated many times throughout the novel in association with the Fur Queen. This color not only emphasizes the white atmosphere of snowy Northern Manitoba, where Weesageechak stories are told, but also signals that the figure of the Fur Queen is emblematic of the presence of the white colonizers in the continent, and will always remind the Okimasis of the colonial experience. The Fur Queen appears in different moments in the novel, and it is through 
the eyes of Abraham that she becomes a figure beyond the material world. The caribou hunter sees her when she is coming to give him the kiss as a "white flame" that walks in his direction. The luxurious form that emerges has the image of a Queen, which is a reference to the Queen of the British Empire:

Then the presence began to take on shape-the caribou hunter could just discern a flowing cape seemingly made from fold after fold of white, luxuriant fur, swelling like the surface of a lake. The caribou hunter thought he saw a crown, made of the same white fur, hovering above this cape. And the crown sparkled and flashed with what could have been a constellation. (10)

Abraham Okimasis is totally seduced by this figure and the victory she represents. However, the narrator's description subtly shows the danger of this young body that seduces the caribou hunter, who is also seduced by the Catholic Church and its promises of a good future for his children sent to the boarding school. He sees a young woman "so fair her skin looked chiseled out of arctic frost, her teeth pearls of ice," but "lips streaks of blood," suggesting the suffering that is about to come. When he tells the story of his victory and the kiss of the Fur Queen to his two youngest sons, the fact is transformed into a fairy tale in which the Fur Queen is a goddess who floats up and becomes one with the northern sky, the seven stars of the Great Bear ornamenting her crown. She becomes a fairytale godmother glimmering in the vastness of the universe, waving her wand and watching over the Okimasis brothers.

The dialogue between Indigenous and Western storytelling traditions is observed in this mixture of the Trickster and a fairytale godmother. The most visible intertextual relation is with The Snow Queen (1845), by Hans Christian Andersen. This fairy tale tells the story of two very close friends (Kay and Girda) who are in the process of growing up. The grown-up different perception of things is 
symbolized by the splinter of a mirror that falls into Kay's eye and heart. Kay is kissed by the Snow Queen and cannot remember his childhood past. He decides to follow her, and Girda starts a quest to find her friend. The description of the Snow Queen in her sledge is quite similar to Highway's portrayal of the Fur Queen when the Okimasis brothers are children. When Kay is playing on the street,

a large sledge passed by: it was painted quite white, and there was someone in it wrapped up in a rough white mantle of fur, with a rough white fur cap on his head. The sledge drove round the square twice, and Kay tied on his sledge as quickly as he could, and off he drove with it. (4)

It was a lady; her cloak and cap were of snow. She was tall and of slender figure, and of a dazzling whiteness. It was the Snow Queen. (5)

Not only her physical appearance is similar to the Fur Queen's, but also her kiss signals both survival and destruction. The cold kiss symbolizes the passing of age, which inevitably leads people to death. The Fur Queen's lethal kiss can be perceived in the Snow Queen's warning to Kay when she kisses him: “ 'Now you will have no more kisses,' said she, 'or else I should kiss you to death!' "(5). Girda's meeting with the Narcissus flower and the Snow Queen's frozen lake called the "Mirror of Understanding" point to the theme of this fairytale, which is self-knowledge and understanding of one's experience when growing up. Moreover, the end of the story shows the necessity of remembering one's childhood and keeping the child's view of the world. In Kiss of the Fur Queen, the Fur Queen also appears to the Okimasis brothers to connect them to their childhood and, consequently, to the Indigenous knowledge they had at their home.

The Fur Queen has the trickster's power to transform herself: she is not only the fairytale godmother, but also a creator, a mother, which recalls the centrality of Highway's mythology on the feminine divinity 
- Mother Earth. Her white fur cape becomes the aurora borealis, and from the seven stars on her tiara bursts a human fetus, a ghost child:

The Fur Queen disappeared, leaving her cape and crown, and the ghost child drifting in the womb of space, the wisps of winter cloud its amniotic fluid, turning and turning, with a speed as imperceptible yet certain as the rhythm of the spheres. And slowly, ever so slowly, the ghost baby tumbled, head over heels over head, down, down to Earth. (12)

The ghost baby is the image of the young Champion to be born, who receives this name because he is born right after Abraham's victory. From this moment on, the Fur Queen starts to interfere and participate in the life of the Okimasis family. When Mariesis is going to give birth, she looks at the trophy and the picture of Abraham with the silver bowl receiving the kiss, and sees a light coming from the Fur Queen's eyes. Champion is born on a trapline, when Mariesis, half-closing her eyes, sees the sleeping child, the ghost baby, inside the womb of the night (19).

\section{The Saint and the Weetigo}

Part Two, Andante Cantabile, shows the experience of the two brothers at the Birch Lake Indian Residential School, and it is in this part that the discourse of the Catholic Church is intermingled with Trickster tales. Champion is the first one to leave home, but it is when Mariesis is packing Gabriel's things some time later that she gives him the picture of the kiss of the Fur Queen, saying that the Fur Queen would watch over them (74). The two brothers sleep in the same room at school, but are not allowed to speak Cree to each other, nor have contact with their sister, who is also there with the female group. Before sleeping, they usually kiss their father's Fur Queen photograph, as if they were kissing the image of a saint who would protect them. Indeed, the first time the principal Father Lafleur tries to get closer to Gabriel to 
abuse him, the Fur Queen blocks his actions. He enters the bedroom when Jeremiah is at Gabriel's bed helping him to get asleep, and makes Jeremiah go back to his bed. He looks back to Gabriel and his eye is caught by the photograph: "In the semi-darkness, the moon, playing her usual tricks on glassy surfaces, made the Fur Queen wink" (74). The wink, which signals complicity with Gabriel, also works as protection. Ironically, the Fur Queen is the spiritual entity that protects the children from the Catholic religion, which becomes a threat to the Cree boys. In Brydon's words:

She is there as they are initiated into the hypocrisies of a Christian religion that allows its priests to separate a doctrine of asceticism from their indulgence of an illicit desire for the flesh of little boys. Through her presence she seems to shield them from total destruction by the white man's religion, which is characterized as a potent mix of Christianity, irresponsible lust, and consumer capitalism. (20)

Father Lafleur is the priest who uses his power to sexually abuse the children. Jeremiah's fears regarding Lafleur's approach to his brother anticipates what we come to discover towards the end of the novel: that he had also been a victim of abuse, but tried to overcome the trauma by forgetting his body and dedicating himself to music. In the novel, the narrated scenes of abuse mostly refer to Lafleur abusing Gabriel, and only one scene refers to the abuses suffered by Jeremiah, when he finally faces his trauma and decides to come to terms with his past. While the Trickster, as an Indigenous entity, transforms itself into a saint to protect the Okimasis brothers, Father Lafleur is transformed in the narrative into the Weetigo, an Indigenous evil figure who feasts on human flesh, a beast, a cannibal spirit. Jeremiah sees Lafleur abusing his brother for the first time as a dark, hulking figure hovering over him, like a crow: "Visible only in silhouette, for all Jeremiah knew it might have been a bear devouring a honey-comb, or the Weetigo feasting on human flesh" (79). Father Lafleur faces Jeremiah after his 
"mastication" of the victim, and "[t]he whites of the beast's eyes grew large, blinked once. Jeremiah stared. It was him. Again" (79). The word "again" indirectly refers to Jeremiah's abuse, and also to the evil figure of Cree storytelling, who is not defeated and returns. The "whites" of the beast's eyes, as well as "the intense whiteness of the saints in the catechism book" directly connect the church to the violence of colonialism brought by Whites. This connection is literal when the two grown up brothers are in Ontario in contact with the Ojibway. AnnAdele Ghostrider, the grandmother of Jeremiah's classmate Amanda Clear Sky, tells about the hunger on Mistik Lake, which led people to death, until one day "a man became possessed by Weetigo, the spirit who feasts on human flesh. At this time, the first priest arrived on Mistik Lake" (245-246), with promises of solution to the problems of the community. From an Indigenous point of view, the Weetigo is the best representation of the beast of colonialism and capitalism that is going to threaten and devour Indigenous people, represented in the novel by the sacrificial victim: Gabriel, the dancer. His sacrifice is also emphasized by the figure of Christ, who is crucified. When Lafleur is abusing him, the crucifix that dangles from his neck comes to rest on Gabriel's face, and the "subtly throbbing motion of the priest's upper body made the naked Jesus Christ - this sliver of silver light, this fleshly Son of God so achingly beautiful - rub his body against the child's lips, over and over again" (78).

While the beast sexually devours Gabriel, Jeremiah is consumed by Western culture. He starts denying his Cree identity and acts as if he were White, and his passion for the piano and classical music becomes a perfect strategy to make him forget his origins. He leaves Birch Lake and goes to high school in Winnipeg, where he has the chance to continue his classical music studies. When Gabriel joins him in Winnipeg, the changes in the older brother become more visible, since it is perceived he is losing his Cree accent. Jeremiah also takes Gabriel to a shopping mall in order to buy more appropriate clothes. The mall, a capitalist device that prompts people into consumerism, is also associated with the Weetigo: "Grabbing Gabriel's sleeve, Jeremiah plunged deep into the entrails of the beast" 
(116). The food court is described as "the belly of the beast," where the Okimasis brothers are devoured, to be expelled when they leave the mall: "Grey and soulless, the mall loomed behind them, the rear end of a beast that, having gorged itself, expels its detritus" (121). It is when the two brothers are at the food court that Gabriel questions Jeremiah about the story of the Weetigo, asking why Weesageechak killed him. Jeremiah's answer - that the Weetigo had to be killed because he ate people - reinforces the fight against the evil colonial forces that devour the soul of the Cree boys: the church and capitalism.

In Winnipeg, Gabriel develops his talent as a dancer, while he enters the sacrificial process of promiscuity. Although living his homosexuality also represents a choice to overcome the trauma of sexual abuse, his masochistic experiences, which lead him into prostitution and self-destruction, point to the negative consequences of the violence undergone at the residential school. Promiscuity is also an expression of the Weetigo's actions, as can be noticed in the description of Gabriel's sexual relationships in a living-room inside a bar, called The Rose, where he got drunk, despite being just fifteen. There, "the body of the caribou hunter's son was eaten, tongues writhing serpent-like around his own, breath mingling with his, his orifices punctured and repunctured, as with nails." At this moment, the sexual violence in the boarding school comes to his mind, symbolized by the crucifix: "somewhere in the farthest reaches of his senses, the silver cross oozed in and out, in and out, the naked body pressing on his lips, positioning itself for entry. Until, upon the buds that lined his tongue, warm honey flowed like river water over granite" (169).

The tumultuous changes happen in Part IV, Molto Agitato, and Jeremiah's crisis coincides with his father's death and the family reunion in Eemanapiteepitat. The words pronounced by Abraham Okimasis, and the story he tells about the Son of Ayash, are crucial to explaining Gabriel and Jeremiah's role, although the father could never imagine that the evil he talks about is brought by the church he defends until his death. In the story, the mother says to her son that the world has become too evil, so he would have to use his magic weapons to make a new 
world: "So the Son of Ayash took the weapons and, on a magic water snake, journeyed down into the realm of the human soul, where he met evil after..." In the middle of Catholic death rituals, Abraham talks to Gabriel and brings up Cree mythology to emphasize the evil that needs to be faced by the hero: " 'Evil after evil,' continued the hunter, 'the most fearsome among them the man who ate human flesh" "(227). Abraham's last words announce his youngest son's destiny, which is sealed in the double-coded language of trickster discourse. The appearance of the Fur Queen in this death scene, who "raised her lips from the world champion's cheek, exhaling a jet of pure white vapour" (228), reinforces the message of death and victory that is connected to the boys' journey.

\section{The Trickster Wink}

The climax of the novel is the conflict between Christian and Cree mythologies, which leads to the victory of the Trickster in Gabriel's death scene. After Gabriel leaves the reserve in the episode of Abraham's death, Jeremiah gets drunk to end up meeting the Fur Queen in his dream, in a state of delirium. The Trickster appears to Jeremiah through a figure that is a mixture of an arctic fox and a human being, and introduces herself first as Miss Maggie Sees, a showgirl. This unusual figure finally says she is "Miss Maggie-WeesageechakNanabush-Coyote-Raven-Glooscap-oh-you-should-hear-the-thingsthey-call-me-honeypot-Sees, weaver of dreams, sparker of magic, showgirl from hell" (234). At this point, the Trickster becomes an entity to tell Jeremiah that "without entertainment, without distraction, without dreams, life's a drag" (233). Moreover, these words highlight Highway's concern that the Trickster is a religious figure like a god, but outside the Christian definitions of good and evil. Finally, she defies the superiority of the omnipotent Christian God, showing the absurdity of such an authority from an Indigenous viewpoint: "Show me the bastard who come up with this notion that who's running the goddamn show is some grumpy, embittered, sexually frustrated old fart with a 
long beard hiding like a gutless coward behind some puffed-up cloud and I'll slice his goddamn balls off" (234).

Jeremiah joins Gabriel in Toronto, where after a time of drunkenness and no more contact with the piano, he finds his way back working with theatre for children in the Friendship Center, and composing for his Indigenous plays in which Gabriel performs. Jeremiah's production is described as a "Cree rite of sacrifice" (280), which works as a metafictional device that reproduces the events to happen in the novel. Gabriel is the Son of Ayash who uses his magic weapons to defeat the Weetigo. Although he dies, the trickster Fur Queen works as a magic weapon that makes his death not an end, but a sacrificial rite to defeat the evils of colonialism. Jeremiah needs to learn something through Gabriel's sacrifice, and the death scene at the hospital is his moment of insight.

Gabriel is the defender of an Indigenous Religion, the defender of the Trickster, and compared on stage to "Dionysus," the Greek god that is most closely associated with the Trickster's defense of entertainment, pleasure, dreams and laughter. It is by Gabriel's death that Jeremiah realizes the importance of connecting with his storytelling roots and Cree spirituality, which are still alive in Canada. The death scene in the hospital, which in a certain way duplicates the death of the father, is the conclusion of the novel and the climactic moment in which the trickster Fur Queen takes over to bring a promise of survival. When Gabriel asks if Jeremiah knows who their father met on the other side, Gabriel himself guarantees it was not Jesus, but Weesageechak, now disguised as the Fur Queen:

"The Trickster, of course," Gabriel finally answered himself, "Weesageechak for sure. The clown who bridges humanity and God - a God who laughs, a God who's here, not for guilt, not for suffering, but for a good time. Except, this time, the Trickster representing God as a woman, a goddess in fur. Like in this picture. I've always thought that, ever since we were 
little kids. I mean, if Native languages have no gender, then why should we? And why, for that matter, should God?" (298)

Gabriel's option for the Cree figure of Weesageechak and not the Catholic God is confirmed when he demands from Jeremiah that no priest is near his bed when he dies. His death scene is emblematic of the conflict between these two forces: "Below the Fur Queen portrait, Mariesis's rosary lay entwined in Gabriel's fingers. Ann-Adele Ghostrider's old, brown hand removed the beads and replaced them with an eagle feather" (303). The Catholic rites are replaced by an Indigenous ceremony, and while Mariesis and the priest scream outside the room to let them in, Jeremiah locks the door and decides to defend his brother's wishes and his own Cree identity: " 'There's a man dying in here!' Jeremiah cried. 'We're Indians! We have a right to conduct our own religious ceremonies, just like everyone else!' " (305).

Gabriel visualizes the moment when he is dying as his own sled race towards the Fur Queen, or his final meeting with the Trickster, which comes to confirm that it is this Cree entity he meets on the other side. Hence, the double nature of this figure is that, at the same time she announces death with her kiss, she also proclaims the victory of Cree knowledge and spirituality over the colonial impositions. As happened to his father in the sled race victory, he starts to discern this young woman so fair her skin looked chiseled from arctic frost. In the language of a fairy-tale, the end of the novel tells the meeting between Gabriel and the Fur Queen, whose sash, now with the date of 1987, symbolizes the victory that his death represents:

And as he moved ever closer, Gabriel Okimasis could decipher the words and the numerals printed across her sash, syllable by syllable, letter by letter: "The Fur Queen, 1987." (...) And then the Queen's lips descended. Down they came, fluttering, like a leaf from an autumn tree, until they came to rest if only for a moment, though he wanted it to last a 
thousand years, on Gabriel Okimasis's left cheek. There. She kissed him. And took him by the hand. (306)

This scene transcends the facts of the spiritual realm to communicate with the material world, so that a connection with Jeremiah is established. Rising from his body, Gabriel Okimasis and the Fur Queen floated off into the swirling mist, and "the little white fox on the collar of the cape turned to Jeremiah. And winked" (306).

The wink becomes a symbol more powerful than any other characteristic or attitude of the Fur Queen. As Brydon states, it is an invitation to complicity, an ironic acknowledgement of doubleness, since the priest and his God have been outwitted and Cree perspectives survive, but in reconstituted and ambiguous forms (21). The wink also works as a device that prompts the double nature of trickster discourse, signaled by irony and a tragicomic mode. The Fur Queen winks when Lafleur first tries to approach Gabriel in his bed. She also winks at the situation when Mariesis and Aunt Kookoos Cook visit Jeremiah in Winnipeg. Mariesis is saying they should never forget what they have learned at residential school, while Jeremiah is writing the fourth scene of his play that tells a darker version of the first missionary's arrival on Mistik Lake. This ironic situation is mentioned by Richard Lane, who points out that the questioning here concerns not only what kind of Christianity should be remembered, but also that remembering the abuse is also a way of healing according to a trickster perspective (195). Even the Jesus on the wall above the piano performs the Fur Queen's wink when Jeremiah has the idea of sending a tape with his music to his family for Christmas and New Year's Day. In all these cases, it is with Jeremiah that the Trickster tries to communicate and send his ironic message of doubleness, which shows that Cree knowledge can survive in Canadian culture through adaptation. The connection between Jesus and the Fur Queen promoted by the wink also relates Gabriel's sacrificial death to Jesus' crucifixion to save humans from their sins. However, this relationship stresses that it is not Jesus that saves the Cree boys from their experience of oppression, but the Fur Queen, the 
Trickster that reemerges after the colonial experience in the Canadian territory as the female figure in fur.

In Kiss of the Fur Queen, the main characters have two names, speak two tongues, live in two worlds, and can only live their Cree culture and spirituality through the figure of Weesageechak transformed into a Fur Queen. The Fur Queen emerges as an ambiguous symbol that recovers Cree tradition to adapt it into a new context. Doubleness and ambiguity are central and conflicting in the novel, as in Gabriel's face when he looks in a cracked mirror that slices his image in two (274). Gabriel's face in the mirror reminds us of the splinters that go into Kay's eyes and heart in The Snow Queen to signal the changes of perception that mark his growing-up journey. Not only selfknowledge is stressed at this point in the novel, but also the awareness of this double and cracked identity. When Howells points to the differences between Joyce's Portrait of the Artist as a Young Man and Highway's novel, she also focuses on the double logic in which the text is constructed. We have the life of two artists, which is emblematic of the duplicity of language and culture that pervades the literary text. The question of the double ${ }^{1}$ has been analyzed from psychological, sociological and literary perspectives. However, in Highway's novel, the double does not concern a self that rejects the other, like Freud's ideas on the return of the repressed, nor Poe's and Dostoyevsky's explorations of double personality in which one pole is totally antagonistic to the other. Gabriel's awareness is that, although he is fractured by their double condition and the evils of colonialism, he Gabriel/Dancer - can only exist as a product of these two worlds, a conjunction of these two realities.

The concept of adaptation as developed by Wilke and De Souza is an important device when pursuing an Indigenous-centered perspective for the analysis of the novel, and Highway's novel supports the idea that the Cree trickster survives and lives in Canada through new guises. Moreover, trickster stories also need to adapt themselves into Western literary genres in order to communicate through a written 
discourse. The experience of adapting trickster storytelling tradition into the novel evokes J. Edward Chamberlin's concerns about the untranslatability that is part of this enterprise. While Chamberlin stresses the necessity of acknowledging storytelling as a ceremony of belief (2), therefore as a performance in which not only the words, but the gestures and the elements used construct meaning, he also states that it is the contradiction involved in stories that approximates different cultures, because all stories involve ceremony, performance and beliefs (239). English cannot fully translate what Gabriel's death signifies in a context of stories about Weesageechak. On the other hand, EuroCanadian culture becomes necessary to explain Cree experience in contemporary Canada. This agonistic feeling of depending on a culture that cannot fully translate one's own and has a history of destruction of Indigenous traditions is a paradox in the novel.

The duality expressed by the necessity of both Cree and English can be observed in the comic and tragic characteristics of trickster discourse. In this double language, Gabriel's tragic death is also a reason for celebration, which is anticipated by the two epigraphs. The first one is from Duncan Campbell Scott, Deputy Superintendent General of the Department of Indian Affairs (1921), forbidding the practice of dancing in First Nations communities. Dancing is a powerful and sacred ritual, which frightens the settlers. Therefore, Gabriel's dancing also becomes a device that empowers the Indigenous community and resists colonial impositions. However, it is the second epigraph that emphasizes how Gabriel's power transcends the decay of his physical body, since the spiritual strength of the Trickster is beyond death. The epigraph by Chief Seattle of the Squamish stresses that Indigenous people will never leave their land, Mother Earth, even when dead:

At night, when the streets of your cities and villages are silent, they will throng with the returning hosts that once filled them, and still love this beautiful land. The whiteman will never be alone. Let him be just and deal with my people. For the dead are not powerless. 
Gabriel is not powerless after his death, since the Fur Queen takes him to the spiritual realm, and Jeremiah remains in the material world to continue their recovery of Cree tradition.

When we come to the heart of what storytelling is, the issue of spirituality must be mentioned, since it is the most difficult aspect to translate into the English literary text. How can an English novel be an experience of spirituality in Cree terms? How can one perceive the humor intrinsic to the Fur Queen's wink at the tragic end of the story? When Jeremiah starts to compose his plays, he faces the untranslatability of Cree poetry into the English language:

Yes, he had written a spot of music - freak accident though that may have been - interspersed with words he dared to claim were poetry, if in Cree. And, yes, the work had been successful, on a very modest scale. But did that make him a dramatist? And in English, that humourless tongue? (273)

English, the "humourless tongue," becomes the mode to translate and adapt trickster storytelling. However, it is precisely within that space of untranslatability, best expressed by the Fur Queen's wink, a tricky device that cannot be fully grasped by the non-Indigenous reader, that resistance occurs. This space is the realm of Cree spiritual power, which can never be defeated. When Brydon acknowledges the necessity of Gabriel's death in the novel, she shows that the fox's wink marks a conclusion that is also a beginning, because it is "the gesture of the trickster, the compromised compromiser, a type of culture-hero incomprehensible to the Manichean imagination" (24). The open end of the novel and the fox's wink to Jeremiah signal the necessity of agency, which becomes Jeremiah's mission.

Pain and suffering in Kiss of the Fur Queen are part of the trickster discourse that aims at healing, while the wink signals that Gabriel's death outwits the Weetigo and reminds Jeremiah of his spiritual roots. The Trickster's power remains after the death of the hero, and Jeremiah participates in this healing ritual. His role, then, is to keep on changing 
the world with the magic weapons of the Indigenous artist, represented by the novel, the music, the plays, and the storytelling tradition that is resurrected. Art is a strategic and powerful terrain in which the Okimasis brothers, and Highway himself, can meet the Fur Queen and recover the spiritual strength necessary for Indigenous existence in contemporary Canada. Highway's acknowledgement of art and literature as a space of transformation and survival in his novel demands a concept of genre as a performative structure, such as the one developed by Frow. This approach respects the function of storytelling in Cree culture, so that the narrative genre becomes a space in which the oral tradition is transformed and revitalized when reinscribed into Western literary genres to perform a symbolic action of resistance to colonial discourses. However, the aspect of continuity and survival that characterizes Trickster tales reminds us that the end of a story is just another beginning, and the tension continues, because the Weetigo is still a threat, and must still be defeated by Weesageechak.

\section{Note}

1. In " 'Power' in literature and society: the 'double' in Gabriel García Marquez's The autumn of the patriarch," José Anadón acknowledges many studies on the double, but states that Latin American works have been largely ignored by European and North American critics. Psychological approaches to the double have been made by Sigmund Freud, Otto Rank and Robert Rogers. While Freud focuses on the "uncanny" and "the return of the repressed", Rank and Rogers consider the literary doubles as projections of their creators, who try to express and deal with their own internal, psychological conflicts. In romantic literature, it has been recognized either as a product of the writers of the German Romantic Movement, derived from the subjective idealism and resulting in a dualistic splitting of the world, or more simply as a denial of death in the modern world. Tzvetan Todorov refers to the double when he analyzes fantastic literature in Introduction a la litterature fantastique. Paris: Seuil, 1970. In Latin America, Jorge Luis Borges recognizes the double as one of the four major elements in fantastic literature. Examples of the double in literature can be found in works by Edgar Allan Poe, Dostoyevsky, Jorge Luis Borges, among many other writers. 


\section{References}

Andersen, Hans Christian. "The Snow Queen". The Literature Network. Available at: http://www.online-literature.com/hans_christian_andersen/972/. 28 October 2009.

Brydon, Diana. "Compromising Postcolonialisms: Tomson Highway's Kiss of the Fur Queen and contemporary postcolonial debates". Compr(om)ising Post/ Colonialism(s): Challenging Narratives and Practices. Ed. Greg Ratchiffe and Gerry Turcotte. Sydney: Dangaroo, 2001.15-29.

Chamberlin, J. Edward. If This Is Your Land, Where Are Your Stories?: Finding Common Ground. Toronto: Alfred Knopf, 2003.

Cruikshank, Julie. Life Lived Like a Story. Vancouver: UBC Press, 1990. . The Social Life of Stories: Narrative and Knowledge in the Yukon Territory. Vancouver: UBC Press, 1998.

De Souza, Lynn Mario T. M. "Remapping writing: indigenous writing and cultural conflict in Brazil." English Studies in Canada 30:3: 4-16.

Foucault, Michel. The Archaeology of Knowledge. Trans. A. M. Sheridan Smith. London: Routledge, 1989.

Frow, John. Genre. New York: Routledge, 2005.

Highway, Tomson. The Rez Sisters. Calgary: Fifth House, 1988. . Dry Lips Oughta Move to Kapuskasing. Calgary: Fifth House, 1989. . Kiss of the Fur Queen. Toronto: Doubleday Canada, 1998. . Comparing Mythologies. Ottawa: University of Ottawa Press, 2003. . Rose. Vancouver: Talonbooks, 2003.

Howells, Coral Ann. “Towards a recognition of being: Tomson Highway's Kiss of the Fur Queen and Eden Robinson's Monkey Beach." Revista Canaria de Estudios Ingleses 43: 145-159. 
Lane, Richard. "Surviving the residential school system: Canadianness in Tomson Highway's Kiss of the Fur Queen." Reconfigurations: Canadian literatures and postcolonial identities/Littératures canadiennes et identities postcoloniales. Ed. Marc Maufort and Franca Bellarsi. Brussels/Bruxelles: PIE-Peter Lang, 2002. 191- 201.

Lévi-Strauss, Claude. Antropologia Estrutural. Trans. Chaim Samuel Katz and Eginardo Pires. Rio de Janeiro: Tempo Brasileiro, 1967.

. Antropologia Estrutural II. Trans. Maria do Carmo Pandolfo. Rio de Janeiro: Tempo Brasileiro, 1989.

Maracle, Lee. "Oratory on Oratory." Trans.Can.Lit: Resituating the Study of Canadian Literature. Ed. Smaro Kamboureli and Roy Miki. Waterloo: Wilfrid Laurier, 2007. 55-70.

Shackleton, Mark; Lutz, Hartmut. "Interview with Tomson Highway." Kunapipi: Journal of Post-Colonial Writing 25:2: 74-85.

Wilke, Gundula. "Traditional values and modern concerns: the Committee to Reestablish the Trickster." Revista Canaria de Estudios Ingleses 35: 135-149. 